\title{
Analisis Faktor-Faktor yang Mempengaruhi Kinerja Sistem Informasi Akuntansi pada Lembaga Perkreditan Desa
}

\author{
Gita Najmi Safitri ${ }^{1}$ \\ Fakultas Ekonomi dan Bisnis \\ Universitas Udayana, Indonesia
}

\author{
I Made Pande Dwiana Putra² \\ Fakultas Ekonomi dan Bisnis \\ Universitas Udayana, Indonesia
}

\begin{abstract}
Surel : githasavitri490@gmail.com
ABSTRAK

Penelitian ini bertujuan untuk megetahui pengaruh variabel keterlibatan pengguna dalam pengembangan sistem, program pelatihan dan pendidikan pemakai, kemampuan teknik personal, komunikasi pengguna dan pengembang sistem informasi dan ukuran organisasi pada kinerja Sistem Informasi Akuntansi (SIA). Responden dalam penelitian ini sebanyak 40 orang karyawan yang terdapat pada Lembaga Perkreditan Desa (LPD) di Kecamatan Denpasar Selatan. Penentuan sampel menggunakan metode purposive sampling. Alat analisis yang digunakan adalah analisis regresi berganda. Hasil penelitian ini menunjukkan bahwa variabel keterlibatan pengguna dalam pengembangan sistem, program pelatihan dan pendidikan pemakai, kemampuan teknik personal, komunikasi pengguna dan pengembang sistem informasi dan ukuran organisasi berpengaruh positif signifikan pada kinerja SIA.
\end{abstract}

Kata Kunci: Keterlibatan Pengguna; Pelatihan dan Pendidikan; Teknik Personal; Komunikasi Pengguna dan Pengembang.

\section{Analysis Of Factors That Influence Performance Accounting Information Systems In Institutions Village Credit}

\section{ABSTRACT}

This study aims to determine the effect of user involvement variables in system development, user education and training programs, personal technical skills, user communication and information systems developers and organizational size on the performance of the Accounting Information System. Respondents in this study were 40 employees found in the LPD in South Denpasar District. Determination of the sample using purposive sampling method. The analytical tool used is multiple regression analysis. The results of this study indicate that the variables of user involvement in system development, user training and education programs, personal technical skills, user communication and information system developers and organizational size have a significant positive effect on SIA performance.

Keywords: $\quad$ User Involvement; Training and Education; Personal Engineering; User and Developer Communication.

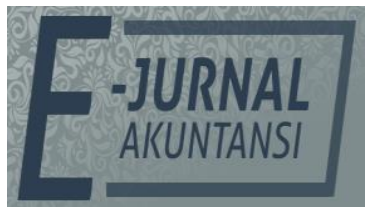

e-ISSN 2302-8556

Vol. 31 No. 2

Denpasar, Februari 2021

Hal. 414-426

DOI:

10.24843/EJA.2021.v31.i02.p12

PENGUTIPAN:

Safitri, G.N., \& Putra I M.P.D. (2021). Analisis

Faktor-Faktor yang

Mempengaruhi Kinerja Sistem Informasi Akuntansi pada Lembaga Perkreditan

Desa. E-Jurnal Akuntansi, 31(2), 414-426

RIWAYAT ARTIKEL: Artikel Masuk: 1 Juli 2020

Artikel Diterima: 8 Februari 2021

Artikel dapat diakses : https://ojs.unud.ac.id/index.php/Akuntansi/index 


\section{PENDAHULUAN}

Perkembangan teknologi informasi telah menyebabkan beralihnya penggunaan sistem informasi yang berbasis computer (Ariyanto et al., 2020). Penerimaan dan pemanfaatan sistem informasi yang berbasis komputer, tidak hanya berfungsi sebagai sarana pendukung untuk meningkatkan kinerja perusahaan, tetapi telah menjadi senjata utama untuk menghadapi persaingan. Penggunaan teknologi informasi diharapkan dapat memberikan manfaat yang besar dalam dunia bisnis yang sangat kompetitif (Wirawan \& Suardikha, 2016). Sistem informasi sangat penting dalam lembaga guna menunjang kelancaran kinerja lembaga, termasuk pada Lembaga Perkreditan Desa (LPD). Kurniawati \& Dwirandra (2017) menyatakan banyaknya lembaga keuangan yang semakin berkembang di Denpasar Selatan membuat persaingan kian kompetitif (Muliartha RM, 2020). Fenomena yang terjadi di LPD Denpasar Selatan menurut salah satu narasumber di Lembaga Pemberdayaan Lembaga Perkreditan Desa (LPLPD) tersebut bahwa masih adanya beberapa LPD di Kota Denpasar Selatan yang belum secara optimal menggunakan sistem informasi akuntasi secara intergritas dan komputerisasi. Karena dalam penerapannya tidak sedikit karyawan di LPD Kecamatan Denpasar Selatan kurang percaya diri dalam mengoperasikan Sistem Informasi Akuntansi (SIA) yang ada. Hal tersebut diakibatkan karena karyawan yang sudah memiliki usia tidak muda lagi, dimana sebelumnya mereka terbiasa bekerja mengolah data dengan proses manual (Veriana \& Budiartha, 2016). Melihat permasalahan tersebut, maka perlu diteliti apakah kinerja SIA di LPD Kecamatan Denpasar Selatan sudah baik sesuai harapan atau belum.

Mardiana et al. (2014) menjelaskan bahwa penggunaan sistem informasi akuntansi sebagai salah satu sistem paling penting yang dimiliki organisasi telah mengubah cara menangkap, memproses, menyimpan, dan mendistribusikan informasi. Keberhasilan sistem informasi suatu perusahaan tergantung bagaimana sistem tersebut dijalankan, kemudahan sistem bagi para pemakainya dan pemanfaatan teknologi yang digunakan, sehingga sistem informasi akuntansi sebagai satu fasilitas utama perusahaan untuk menghasilkan informasi yang berkualitas dan sekaligus menjadi salah satu strategi bisnis bagi perusahaan (Ariyanto et al., 2014). Perusahaan akan memiliki daya saing yang tinggi jika dapat memanfaatkan informasi sebagai sumber utama untuk melakukan segala aktivitas bisnis. O'Brien \& Marakas (2010) menyatakan bahwa keberhasilan dari sebuah sistem informasi tidak hanya diukur dari efisiensi dalam hal meminimalisasi biaya, waktu, dan penggunaan sumber daya informasi. Keberhasilan sistem informasi perlu didukung dari beberapa faktor yang dapat membentuk keberhasilan dari sistem informasi itu sendiri yang dapat dilihat dari kepuasan dan pemakain sistem informasi tersebut (Suryawarman \& Widhiyani, 2012). Menilai kinerja sistem informasi akuntansi (SIA) untuk membentuk keberhasilan pengembangan sistem itu sendiri merupakan masalah yang penting, sehingga dapat memberikan nilai tambah. Pengukuran kinerja dapat diukur melalui sudut pandang pemakai (user) dengan menggunakan dua aspek, yaitu aspek kepuasan pemakai Gefen \& Straub, (2000) dan Juliarsa, (2012) dan pemakai sistem informasi akuntansi (Alannita \& Suaryana, 2014), dan (Jayantara \& Dharmadiaksa, 2016). Kepuasan dari pemakai sistem informasi akuntansi menunjukkan seberapa jauh pemakai merasa senang dan percaya terhadap sistem informasi yang digunakan 
untuk menghasilkan informasi yang tepat waktu sedangkan pemakaian sebuah sistem informasi apabila frekuensi penggunanya sering maka sistem itu dikatakan baik (Antari et al., 2015). Insani (2017) menyatakan untuk menghindari kegagalan sistem, maka perlu diketahui faktor-faktor apa saja yang mempengaruhi efektivitas atau keberhasilan implementasi suatu sistem informasi.

Faktor-faktor yang berpengaruh terhadap kinerja sistem informasi akuntansi yang diteliti dalam penelitian ini antara lain keterlibatan pengguna dalam pengembangan sistem informasi, program pelatihan dan pendidikan pemakai, kemampuan teknik personal, komunikasi pengguna dan pengembang sistem informasi, dan ukuran organisasi. Penelitian tentang pengaruh sistem informasi akuntansi terhadap kinerja suatu perusahaan telah banyak dilakukan namun hasil dari masing-masing penelitian tersebut ada yang mendukung dan sebagian masih kontradiktif. Dalam penelitian Pradnyana \& Dharmadiaksa (2018), dinyatakan bahwa kemampuan personal, pelatihan kerja dan keterlibatan pemakai bermanfaat dalam meningkatkan kinerja sistem informasi akuntansi. Berdasarkan penelitian Widyantari \& Suardikha (2016) menyatakan bahwa keterlibatan pengguna dalam pengembangan sistem informasi, kemampuan teknik personal, dan ukuran organisasi berpengaruh signifikan terhadap kinerja SIA. Sedangkan program pelatihan dan pendidikan pemakai dan komunikasi pengguna dan pengembang sistem informasi tidak berpengaruh signifikan terhadap kinerja SIA.

Penelitian ini mengacu pada penelitian Pradnyana \& Dharmadiaksa (2018) namun terdapat perbedaan antara penelitian ini dengan penelitian yang direplikasi yaitu dari sisi perusahaan yang dijadikan objek penelitian. Objek dalam penelitian ini adalah lembaga perkreditan desa (LPD) yang ada di Kecamatan Denpasar Selatan. Alasan penulis mengambil lembaga perkreditan desa (LPD) sebagai objek penelitian karena sistem informasi akuntansi di LPD berperan penting dalam memproses data akuntansi menjadi infomasi keuangan yang bermanfaat bagi manajemen serta masyarakat, sedangkan penelitian yang direplikasi menggunakan bank umum sebagai objek penelitiannya. Perbedaan variabel yang digunakan dalam penelitian ini dengan yang direplikasi. Dalam penelitian ini digunakan 5 variabel independen yaitu pengaruh keterlibatan pengguna dalam pengembangan sistem informasi, program pelatihan dan pendidikan pemakai, kemampuan teknik personal, pengaruh komunikasi pengguna dan pengembang sistem informasi, dan ukuran organisasi. Sedangkan penelitian yang direplikasi menggunakan 3 variabel yaitu pengaruh keterlibatan pengguna dalam pengembangan sistem informasi, program pelatihan dan pendidikan pemakai, kemampuan teknik personal. Alasannya, untuk menindaklanjuti penelitian-penelitian sebelumnya yang dimana faktor-faktor dari penelitian tersebut ada yang berpengaruh dan ada yang tidak berpengaruh sehingga hasilnya tidak konsisten. Peraturan Daerah Provinsi Bali No. 3 Tahun 2017 pasal 1, menyebutkan LPD adalah lembaga keuangan milik Desa Pakraman yang bertempat di wilayah Desa Pakraman. LPD bertujuan memberi pelayanan kepada nasabah serta lingkungan terkait. Mardiana et al. (2014) menyatakan maksud dan tujuan berdirinya Lembaga Perkreditan Desa adalah untuk mendukung pembangunan ekonomi perdesaan melalui peningkatan kebiasaan menabung masyarakat desa dan menyediakan kredit bagi usaha skala kecil, 
memeratakan perekonomian di desa adat, membuka lapangan kerja dan untuk memberantas gadai dan rentenir. Agar hal tersebut dapat tercapai, maka LPD sebagai suatu organisasi ekonomi dan kegiatan usahanya memerlukan modal yang cukup, yang digunakan untuk membelanjai operasionalnya sehari-hari.

Penelitian ini mengambil lokasi di Kecamatan Denpasar Selatan yang merupakan salah satu kecamatan yang berada di Kota Denpasar. Peran LPD di Kecamatan Denpasar Selatan sangat membantu dalam menjalankan perekonomian masyarakat. LPD di Kecamatan Denpasar Selatan berjumlah 11 LPD yang tersebar di beberapa Desa Pekraman yang berada di Kecamatan Denpasar Selatan. Lembaga keuangan seperti LPD dalam prakteknya bersaing ketat dengan lembaga keuangan keuangan lainnya seperti Bank Perkreditan Rakyat (BPR), koperasi, dan lain sebagainya, sehingga LPD dituntut untuk terus meningkatkan pelayanannya. Salah satu cara meningkatkan pelayanan suatu LPD adalah melalui peningkatan kinerja LPD tersebut.

Laporan keuangan yang lengkap dibutuhkan untuk menilai kinerja suatu LPD (Muliartha RM, 2020), oleh karena itu perlu adanya dukungan SIA dengan teknologi informasi yang terkomputerisasi (Ariyanto et al., 2014) dan (West \& Bhattacharya, 2016). Artinya bahwa bila menginginkan kinerja dari sebuah LPD meningkat penting didukung oleh kinerja sistem informasi yang baik. Kinerja sistem informasi yang baik dapat dihasilkan oleh sebuah LPD dengan dukungan sistem informasi akuntansi yang terkomputerisasi. Selain memperoleh informasi yang akurat dalam pengolahan datanya, sistem informasi yang ada juga mempermudah karyawan dalam pengecekan transaksi dan mempermudah dalam pengambilan keputusan dan pembuatan laporan keuangan. Sistem informasi yang ada juga digunakan untuk memudahkan nasabah dalam melakukan transaksi, pengambilan tabungan, pengecekan saldo dan lain-lain. Dari sistem informasi yang digunakan, maka dapat diketahui bahwa manajemen dari organisasi tersebut baik atau tidak.

Model penerimaan teknologi atau technology acceptace model (TAM) relevan diajukan sebagai pandangan teoritis penggunaan variabel keterlibatan pegguna dalam pengembangan sistem informasi (F D Davis, 1985), (Fred D. Davis, 1989), (Fred D. Davis \& Venkatesh, 1996), dan (Venkatesh \& Davis, 2000). Karena teori TAM menunjukkan bahwa kegunaan dan kemudahan penggunaan akan mempengaruhi niat individu dalam menggunakan teknologi informasi. Agar sistem informasi mudah digunakan, maka pengguna perlu terlibat dalam proses pengembangan sistem. Keterlibatan pengguna penting dipertimbangkan untuk menghindari resistensi pengguna yang dapat menghambat keberhasilan sistem. Keterlibatan pengguna yang semakin sering akan meningkatkan kinerja SIA dikarenakan adanya hubungan yang positif antara keterlibatan pengguna dalam proses pengembangan sistem informasi dalam kinerja SIA.

Hasil penelitian Damana \& Suardikha (2016), Kharisma \& Juliarsa (2017) dan Nayaka \& Suardikha (2019) menyatakan keterlibatan pengguna berpengaruh positif signifikan terhadap kinerja SIA. Berdasarkan landasan teori dan kajian atas hasil penelitian sebelumnya, maka disusun hipotesis penelitian sebagai berikut.

$\mathrm{H}_{1}$ : Keterlibatan pengguna dalam pengembangan sistem informasi berpengaruh positif terhadap kinerja SIA. 
Technology to Performance Chain (TPC) relevan diajukan sebagai pandangan teoritis penggunaan variabel program pelatihan dan pendidikan pemakai (Goodhue \& Thompson, 1995). Karena teori TPC menjelaskan bahwa keberhasilan teknologi sistem informasi yang diimplementasikan dalam suatu perusahaan dapat dinilai berdasarkan evaluasi pemakai. Kemampuan yang dimiliki pemakai sistem informasi diperoleh dari pelatihan dan pendidikan, hal tersebut dapat meningkatkan kepuasan dalam menggunakan sistem informasi, sehingga akan terus menggunakannya dalam membantu menyelesaikan pekerjaannya. Semakin sering pengguna sistem informasi diberikan pelatihan dan pendidikan didalam penggunaan sistem informasi akan berpengaruh terhadap peningkatan kinerja SIA.

Hasil penelitian Ardiwinata \& Sujana (2019), Damana \& Suardikha (2016), dan Jayanti et al. (2017) menyatakan program pelatihan dan pendidikan berpengaruh positif signifikan terhadap kinerja SIA. Berdasarkan landasan teori dan kajian atas hasil penelitian sebelumnya, maka disusun hipotesis penelitian sebagai berikut.

$\mathrm{H}_{2}$ : Program pelatihan dan pendidikan pemakai berpengaruh positif terhadap kinerja SIA.

Technology to Performance Chain (TPC) relevan diajukan sebagai pandangan teoritis penggunaan variabel kemampuan teknik personal (Goodhue \& Thompson, 1995). Karena teori TPC menjelaskan bahwa agar teknologi informasi memberikan dampak positif terhadap kinerja individual maka teknologi tersebut harus dimanfaatkan dan teknologi tersebut harus sesuai dengan jenis pekerjaan yang dilakukan. Jika teknologi yang tersedia cocok dengan tugas yang harus diselesaikan dan kemampuan teknik pemakai, maka pemakai akan memanfaatkan teknologi sistem informasi dalam menjalankan tugas yang dibebankannya. Semakin tinggi kemampuan teknik personal SIA akan meningkatkan kinerja SIA dikarenakan adanya hubungan yang positif antara kemampuan teknik personal SIA dengan kinerja SIA.

Hasil penelitian dari Adisanjaya et al. (2017), Ardiwinata \& Sujana (2019), dan Jayanti et al. (2017) menyatakan kemampuan teknik personal berpengaruh positif signifikan terhadap kinerja SIA. Berdasarkan landasan teori dan kajian atas hasil penelitian sebelumnya, maka disusun hipotesis penelitian sebagai berikut.

$\mathrm{H}_{3}$ : Kemampuan teknik personal berpengaruh positif terhadap kinerja SIA.

Teori TAM relevan diajukan sebagai pandangan teoritis penggunaan variabel komunikasi pengguna dan pengembang sistem informasi (F D Davis, 1985), (Fred D. Davis, 1989), (Fred D. Davis \& Venkatesh, 1996), dan (Venkatesh \& Davis, 2000). Karena teori tersebut menjelaskan bahwa kegunaan dan kemudahan penggunaan akan mempengaruhi niat individu dalam menggunakan teknologi informasi. Agar sistem informasi mudah digunakan, maka pengguna perlu berkomunikasi dengan pengembang dalam proses pengembangan sistem. Apabila sistem informasi mudah digunakan, maka pengguna akan terus menggunakan sistem tersebut dalam menjalankan tugas dan tanggung jawabnya. Sehingga dapat mengasilkan informasi yang akurat dan berdampak pada tercapainya keberhasilan sistem. Semakin tinggi komunikasi dan pengembangan sistem informasi diperusahaan oleh pihak pengembang sistem informasi, akan 
meningkatkan kinerja SIA. Komunikasi yang baik antara pengguna dan pengembang sistem informasi akan meningkatkan kinerja SIA.

Hasil penelitian dari Marfuah \& Handoko (2012) dan Satria \& Dewi (2019) menyatakan komunikasi pengguna dan pengembang sistem informasi berpengaruh signifikan terhadap kinerja SIA. Berdasarkan landasan teori dan kajian atas hasil penelitian sebelumnya, maka disusun hipotesis penelitian sebagai berikut.

$\mathrm{H}_{4}$ : Komunikasi pengguna dan pengembang sistem informasi berpengaruh positif terhadap kinerja SIA.

Teori TAM relevan diajukan sebagai pandangan teoritis penggunaan variabel ukuran organisasi. Karena teori TAM adalah teori sistem informasi yang memuat model mengenai sikap individu untuk menerima dan menggunakan teknologi. Apabila sistem informasi mudah digunakan, maka pengguna akan terus menggunakan sistem tersebut. Sehingga dapat menghasilkan informasi yang akurat dan berdampak pada keberhasilan sistem. Keberhasilan sistem dapat dicapai apabila dana dan sumber dayanya memadai dalam organisasi yang lebih besar. Jika sumber daya tidak memadai, akan memungkinkan perancang sistem tidak dapat mengikuti prosedur pengembangan normal dengan memadai, dengan demikian meningkatkan risiko kegagalan sistem. Kriteria yang paling umum digunakan untuk menentukan besar atau kecilnya ukuran organisasi adalah jumlah karyawan.

Hasil penelitian dari Damana \& Suardikha (2016) dan Fatmawati et al. (2019) menyatakan ukuran organisasi berpengaruh positif signifikan terhadap kinerja. Berdasarkan landasan teori dan kajian atas hasil penelitian sebelumnya, maka disusun hipotesis penelitian sebagai berikut.

$\mathrm{H}_{5}$ : Ukuran organisasi berpengaruh positif terhadap kinerja SIA.

\section{METODE PENELITIAN}

Penelitian ini menggunakan variabel terikat (dependent) yaitu kinerja SIA, variabel bebas (independent) yaitu keterlibatan pengguna dalam pengembangan sistem informasi, program pelatihan dan pendidikan pemakai, kemampuan teknik personal, komunikasi pengguna dan pengembang sistem informasi, dan ukuran organisasi. Penelitian dilakukan pada di Lembaga Perkreditan Desa (LPD) di Kecamatan Denpasar Selatan sebanyak 11 LPD. Jumlah sampel yang diambil sebanyak 40 responden. Pengambilan sampel dalam penelitian ini dilakukan secara nonprobability sampling, yaitu dengan menggunakan pendekatan purposive sampling. Adapun kriteria pengambilan sampel dalam penelitian ini adalah: 1) Karyawan yang sudah menggunakan komputer untuk mengolah data akuntansi. 2) Telah bekerja minimal 1 tahun. Metode pengumpulan data yang digunakan adalah metode survei berupa kuesioner dan dokumentasi. Teknik analisis data yang digunakan pada penelitian ini adalah regresi linier berganda. Pengujian ini dilakukan dengan menggunakan program SPSS. M.odel regre.si linear be.rganda di.rumuskan se.bagai b.erikut.

$$
Y=\alpha+\beta_{1} X_{1}+\beta_{2} X_{2}+\beta_{3} X_{3}+\beta_{4} X_{4}+\varepsilon
$$




\section{HASIL DAN PEMBAHASAN}

Statistik deskriptif dalam penelitian ini digunakan untuk memberikan informasi mengenai variabel-variabel penelitian, antara lain minimum, maksimum, mean dan deviasi standar. Hasil analisis statistik deskriptif dalam penelitian ini disajikan pada Tabel 1, berikut ini.

Tabel 1. Hasil Statistik Deskriptif

\begin{tabular}{lccccc}
\hline & $\mathrm{N}$ & Minimum & Maximum & Mean & Std.Deviation \\
\hline $\mathrm{Y}$ & 40 & 12,00 & 25,00 & 21,9000 & 2,62922 \\
X1 & 40 & 10,00 & 25,00 & 21,5000 & 2,95262 \\
X2 & 40 & 12,00 & 25,00 & 21,4250 & 2,69746 \\
X3 & 40 & 15,00 & 25,00 & 21,8750 & 2,25534 \\
X4 & 40 & 9,00 & 25,00 & 21,2750 & 2,96118 \\
X5 & 40 & 1,00 & 2,00 & 1,4250 & 0,50064
\end{tabular}

Valid N $\quad 40$

(listwise)

Sumber: Data Penelitian, 2020

Tabel 1, Menunjukkan hasil statistik deskriptif dari variabel-variabel yang diteliti, Kinerja SIA (Y) memiliki nilai minimum sebesar 12,00, nilai maksimum sebesar 25,00 dan mean sebesar 21,9000. Standar deviasi untuk kinerja SIA sebesar 2,62922. Hal ini berarti bahwa berdasarkan hasil statistik deskriptif terjadi perbedaan nilai kinerja SIA yang diteliti terhadap nilai rata-ratanya sebesar 2,62922. Variabel Keterlibatan pengguna dalam pengembangan sistem informasi $\left(X_{1}\right)$ memiliki nilai minimum sebesar 10,00, nilai maksimum sebesar 25,00 dan mean sebesar 21,5000. Standar deviasi untuk keterlibatan pengguna dalam pengembangan sistem informasi sebesar 2,95262. Hal ini berarti bahwa berdasarkan hasil statistik deskriptif terjadi perbedaan nilai keterlibatan pengguna dalam pengembangan sistem informasi yang diteliti terhadap nilai rataratanya sebesar 2,95262. Variabel Program pelatihan dan pendidikan pemakai $\left(\mathrm{X}_{2}\right)$ memiliki nilai minimum sebesar 12,00, nilai maksimum sebesar 25,00 dan mean sebesar 21,4250. Standar deviasi untuk program pelatihan dan pendidikan pemakai sebesar 2,69746 Hal ini berarti bahwa berdasarkan hasil statistik deskriptif terjadi perbedaan nilai program pelatihan dan pendidikan pemakai yang diteliti terhadap nilai rata-ratanya sebesar 2,69746. Variabel Kemampuan teknik personal $\left(X_{3}\right)$ memiliki nilai minimum sebesar 15,00, nilai maksimum sebesar 25,00 dan mean sebesar 21,8750. Standar deviasi untuk kemampuan teknik personal sebesar 2,25534. Hal ini berarti bahwa berdasarkan hasil statistik deskriptif terjadi perbedaan nilai kemampuan teknik personal yang diteliti terhadap nilai rata-ratanya sebesar 2,25534. Variabel Komunikasi pengguna dan pengembang sistem informasi $\left(X_{4}\right)$ memiliki nilai minimum sebesar 9,00, nilai maksimum sebesar 25,00 dan mean sebesar 21,2750. Standar deviasi untuk komunikasi pengguna dan pengembang sistem informasi sebesar 2,96118. Hal ini berarti bahwa berdasarkan hasil statistik deskriptif terjadi perbedaan nilai komunikasi pengguna dan pengembang sistem informasi yang diteliti terhadap nilai rata-ratanya sebesar 2,96118. Variabel ukuran organisasi $\left(X_{5}\right)$ memiliki nilai minimum sebesar 1,00, nilai maksimum sebesar 2,00 dan mean sebesar 1,4250. Standar deviasi untuk ukuran organisasi sebesar 0,50064 . Hal ini berarti bahwa 
berdasarkan hasil statistik deskriptif terjadi perbedaan nilai ukuran organisasi

\begin{tabular}{|c|c|c|c|c|}
\hline \multirow{2}{*}{$\begin{array}{c}\text { Uji } \\
\text { Normalitas }\end{array}$} & \multirow{2}{*}{ Variabel } & \multicolumn{2}{|c|}{ Uji Multikolinearitas } & \multirow{2}{*}{$\begin{array}{c}\text { Uji } \\
\text { Heteroskedastisitas }\end{array}$} \\
\hline & & Tolerence & VIF & \\
\hline \multirow[t]{5}{*}{$\begin{array}{l}\text { Signifikan } \\
\mathrm{si}=0,200\end{array}$} & $\begin{array}{l}\text { Keterlibatan pengguna } \\
\text { dalam pengembangan } \\
\text { sistem informasi }\left(X_{1}\right)\end{array}$ & 0,147 & 6,788 & 0,553 \\
\hline & $\begin{array}{l}\text { Program pelatihan dan } \\
\text { pendidikan pemakai }\left(\mathrm{X}_{2}\right)\end{array}$ & 0,241 & 4,148 & 0,873 \\
\hline & $\begin{array}{l}\text { Kemampuan teknik } \\
\text { personal }\left(X_{3}\right)\end{array}$ & 0,206 & 4,859 & 0,079 \\
\hline & $\begin{array}{l}\text { Komunikasi pengguna } \\
\text { dan pengembang sistem } \\
\text { informasi }\left(\mathrm{X}_{4}\right)\end{array}$ & 0,121 & 8,296 & 0,070 \\
\hline & Ukuran organisasi $\left(\mathrm{X}_{5}\right)$ & 0,423 & 2,363 & 0,651 \\
\hline
\end{tabular}

yang diteliti terhadap nilai rata-ratanya sebesar 0,50064.

Uji Asumsi klasik pada penelitian ini yaitu uji normalitas, uji multikolinearitas, dan uji heteroskedastisitas. Hasil uji asumsi klasik dalam penelitian ini dengan bantuan komputer program SPSS Statistik versi 24, dengan hasil sebagai berikut.

\section{Tabel 2. Hasil Uji Asumsi Klasik}

Sumber: Data Penelitian, 2020

Berdasarkan Tabel 2, Menunjukkan bahwa hasil uji normalitas memiliki nilai signifikansi 0,200 > 0,05 yang menunjukkan bahwa data penelitian berdistribusi normal. Berdasarkan Tabel 2, tidak terjadi gejala multikolinearitas. Hal ini ditunjukkan dari nilai tolerance dan VIF dari setiap variabel bebas lebih besar dari 0,1 dan kurang dari 10. Berdasarkan Tabel 2, Diketahui bahwa tidak terjadi gejala heteroskedastisitas dalam model regresi. Hal ini ditunjukkan dari nilai hetoreskedastisitas dari setiap variabel lebih besar dari 0,05.

Hipotesis diuji dengan analisis regresi linier berganda untuk menganalisis variabel independen terhadap variabel dependen dengan menggunakan program SPSS. Hasil Uji regresi linier berganda dapat dilihat pada Tabel 3, Berikut ini.

Tabel 3. Hasil Regresi Linier Berganda

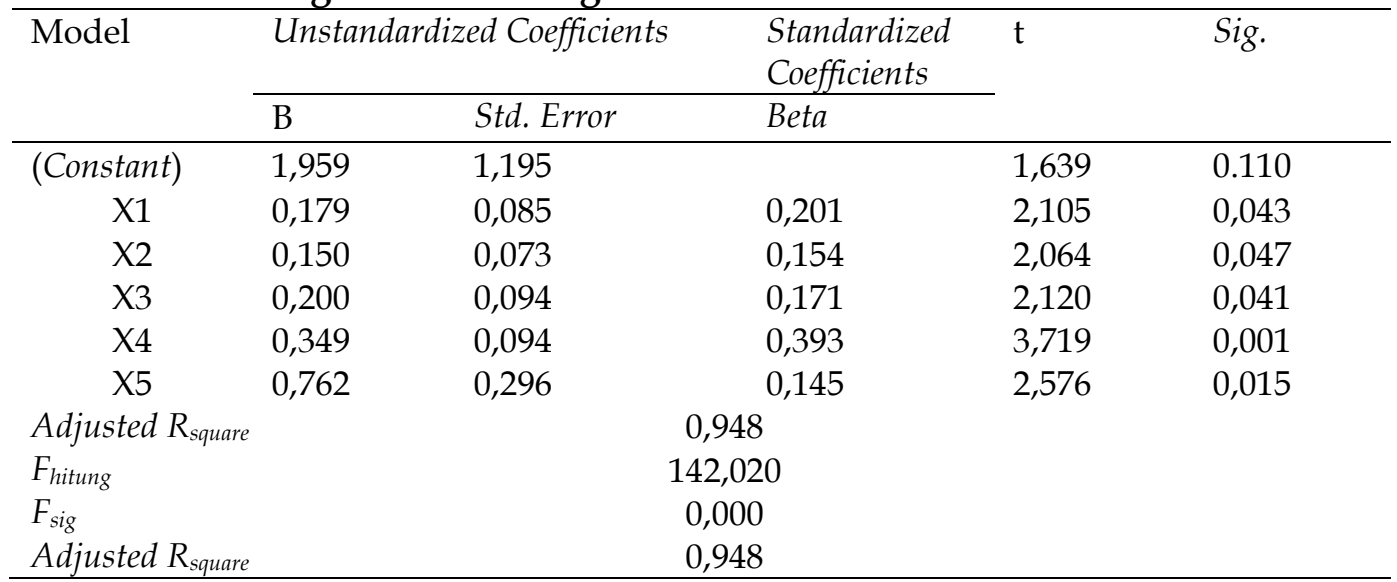

Sumber: Data Penelitian, 2020

Berdasarkan hasil analisis regresi linier berganda pada Tabel 3, model regresi yang terbentuk pada penelitian ini adalah sebagai berikut.

$\mathrm{Y}=1,959+0,179 \mathrm{X}_{1}+0,150 \mathrm{X}_{2}+0,200 \mathrm{X}_{3}+0,349 \mathrm{X}_{4}+0,762 \mathrm{X}_{5}$ 
Nilai konstan sebesar 1,959 artinya, apabila nilai dari variabel keterlibatan pengguna dalam pengembangan sistem informasi $\left(X_{1}\right)$, program pelatihan dan pendidikan pemakai $\left(X_{2}\right)$, kemampuan teknik personal $\left(X_{3}\right)$, komunikasi pengguna dan pengembang sistem informasi $\left(X_{4}\right)$, ukuran organisasi $\left(X_{5}\right)$, sama dengan nol, maka nilai dari variabel kinerja SIA (Y) adalah 1,959. Koefisien variabel keterlibatan pengguna dalam pengembangan sistem informasi $\left(X_{1}\right)$ sebesar 0,179. Hal ini menunjukkan apabila variabel lain konstan, kenaikan 1 satuan variabel keterlibatan pengguna dalam pengembangan sistem informasi akan menyebabkan peningkatan variabel kinerja SIA (Y) sebesar 0,179. Nilai koefisien variabel program pelatihan dan pendidikan pemakai $\left(X_{2}\right)$ sebesar -0,150. Hal ini menunjukkan apabila variabel lain konstan, kenaikan 1 satuan variabel program pelatihan dan pendidikan pemakai akan menyebabkan peningkatan variabel kinerja SIA (Y) sebesar 0,150. Nilai koefisien variabel kemampuan teknik personal $\left(X_{3}\right)$ sebesar 0,200. Hal ini menunjukkan apabila variabel lain konstan, kenaikan 1 satuan variabel kemampuan teknik personal akan menyebabkan peningkatan variabel kinerja SIA (Y) sebesar 0,200. Nilai koefisien variabel komunikasi pengguna dan pengembang sistem informasi $\left(X_{4}\right)$ sebesar 0,349 . Hal ini menunjukkan apabila variabel lain konstan, kenaikan 1 satuan variabel komunikasi pengguna dan pengembang sistem informasi akan menyebabkan peningkatan variabel kinerja SIA (Y) sebesar 0,349. Nilai Koefisien variabel ukuran organisasi $\left(X_{5}\right)$ sebesar 0,762. Hal ini menunjukkan apabila variabel lain konstan, kenaikan 1 satuan variabel ukuran organisasi akan menyebabkan peningkatan variabel kinerja SIA (Y) sebesar 0,762.

Tabel 3, Menunjukkan hasil uji kelayakan model (uji F). Nilai F hitung dalam penelitian ini adalah sebesar 142,020 dengan tingkat signifikansi sebesar 0,000 < 0,05 yang artinya bahwa model regresi layak untuk digunakan. Koefisien determinasi dalam penelitian ini jika dilihat dari nilai adjusted $\mathrm{R}_{\text {square }}$ adalah sebesar 0,948. Ini berarti sebesar 94,8\% variabel-variabel bebas dalam penelitian ini menjelaskan variasi dari kinerja SIA, sedangkan sisanya sebesar 5,2\% dijelaskan oleh variabel lain diluar model.

Nilai signifikansi Uji $\mathrm{t}$ untuk variabel keterlibatan pengguna dalam pengembangan sistem informasi adalah 0,043 dengan nilai koefisien regresi sebesar 2,105, karena tingkat signifikansinya lebih kecil dari alpha 0,05 ini berarti variabel keterlibatan pengguna dalam pengembangan sistem informasi berpengaruh positif signifikan terhadap kinerja SIA. Hal ini berarti dengan berpartisipasi dalam setiap tahapan dalam proses pengembangan sistem informasi, pengguna dapat menyampaikan keinginan-keinginan mereka terhadap sistem yang ada, serta dapat memperoleh manfaat dari pengembangan sistem informasi tersebut, sehingga dapat menimbulkan kepuasan bagi pengguna sistem informasi tersebut yang berpengaruh terhadap keberhasilan sistem yang dikembangkan.

Nilai signifikansi Uji $\mathrm{t}$ untuk variabel program pelatihan dan pendidikan pemakai adalah 0,047 dengan nilai koefisien regresi sebesar 2,064, karena tingkat signifikansinya lebih kecil dari alpha 0,05 ini berarti variabel program pelatihan dan pendidikan pemakai berpengaruh positif signifikan terhadap kinerja SIA. Hasil ini menjelaskan adanya pelatihan pemakai menyebabkan pemakai 
mendapatkan kemampuan untuk mengidentifikasi persyaratan informasi mereka serta dapat mengatasi keterbatasan sistem informasi sehingga pemakai dapat dengan mudah mengikuti proses dari pengembangan sistem dan adanya pendidikan pemakai dalam penggunaan sistem membuat pemakai dapat dengan mudah dalam mengoperasikan sistem dikarenakan terdapat persamaan beberapa sistem pada perusahaan yang sesuai dengan apa yang diperolehnya dari pendidikan .

Nilai signifikansi Uji t untuk variabel kemampuan teknik personal adalah 0,041 dengan nilai koefisien regresi 2,120, karena tingkat signifikansinya lebih kecil dari alpha 0,05 ini berarti variabel kemampuan teknik personal berpengaruh positif signifikan terhadap kinerja SIA. Hasil ini menjelaskan bahwa adanya kemampuan teknik pemakai yang baik, menyebabkan pemakai terdorong untuk menggunakan SIA. Hal ini dikarenakan terdapat persamaan beberapa sistem pada perusahaan yang sesuai dengan apa yang diperolehnya dari pengalaman menggunakan sistem. Hal ini mengakibatkan kepuasan dalam menggunakan SIA cukup tinggi sehingga kinerja SIA yang digunakan meningkat.

Nilai signifikansi Uji $t$ untuk variabel komunikasi pengguna dan pengembang sistem informasi adalah 0,001 dengan nilai koefisien regresi sebesar 3,719 karena tingkat signifikansinya lebih kecil dari alpha 0,05 ini berarti variabel komunikasi pengguna dan pengembang sistem informasi berpengaruh positif signifikan terhadap kinerja SIA. Hasil ini menjelaskan bahwa terjadi komunikasi yang efektif antara pengguna dan pengembang sistem informasi dalam proses pengembangan sistem informasi dan pengorganisasian sistem informasi dalam perusahaan yang terjadi karena pengguna dan pengembang sistem cenderung memiliki persamaan dalam latar belakang, kepentingan dan prioritas.

Nilai signifikansi Uji t untuk variabel ukuran organisasi adalah 0,015 dengan nilai koefisien regresi sebesar 2,576 karena tingkat signifikansinya lebih kecil dari alpha 0,05 ini berarti variabel ukuran organisasi berpengaruh positif signifikan terhadap kinerja SIA. Hal ini terjadi karena ukuran organisasi yang besar dapat menghasilkan sistem informasi yang lebih baik, karena didukung oleh jumlah karyawan yang memadai. Jika jumlah karyawan memadai, akan memungkinkan perancang sistem dapat mengikuti prosedur pengembangan normal dengan memadai, dengan demikian menurunkan resiko kegagalan sistem. Sehingga pemakai merasa puas untuk menggunakan sistem informasi yang ada.

\section{SIMPULAN}

Berdasarkan dari hasil analisis, simpulan penelitian ini adalah: keterlibatan pengguna dalam pengembangan sistem informasi berpengaruh positif signifikan terhadap kinerja SIA yang ditunjukkan dengan nilai signifikansi 0,043, program pelatihan dan pendidikan pemakai berpengaruh positif signifikan terhadap kinerja SIA yang ditunjukkan dengan nilai signifikansi 0,047, kemampuan teknik personal berpengaruh positif signifikan terhadap kinerja SIA yang ditunjukkan dengan nilai signifikansi 0,041, komunikasi pengguna dan pengembang sistem informasi berpengaruh positif signifikan terhadap kinerja SIA yang ditunjukkan dengan nilai signifikansi 0,001 dan ukuran organisasi berpengaruh positif signifikan terhadap kinerja SIA yang ditunjukkan dengan nilai signifikansi 0,015. 
Dari hasil penelitian ini, saran yang dapat diberikan yaitu Lembaga Perkreditan Desa hendaknya melakukan pengembangan sistem informasi akuntansi agar sistem informasi akuntansi yang digunakan mempunyai kinerja operasional yang memadai. Sebaiknya keterlibatan pemakai diharapkan lebih memahami sistem yang diterapkan, program pelatihan dan pendidikan pemakai diadakan dengan rutin, dan diperlukan komitmen organisasi yang efektif terhadap organisasi untuk mempermudah pelaksanaan pengelolaan keuangan yang baik. Pada penelitian berikutnya disarankan agar responden mendapatkan penjelasan yang cukup sebelum melakukan pengisian kuisioner, sehingga pernyataan-pernayatan didalam kuisioner dapat benar-benar dipahami maksudnya oleh responden.

\section{REFERENSI}

Adisanjaya, K., Wahyuni, 1Made Ari, \& Purnamawati, I. G. A. (2017). Pengaruh Kemampuan Personal, Pelatihan Dan Pendidikan Serta Pemanfaatan Teknologi Terhadap Efektivitas Sistem Informasi Akuntansi Pada Mini Market Bali Mardana. E-Journal S1 AK Universitas Pendidikan Ganesha, 7(1). https:// ejournal.undiksha.ac.id/index.php/S1ak/article/view/9318/5996

Alannita, N., \& Suaryana, I. (2014). Pengaruh Kecanggihan Teknologi Informasi, Partisipasi Manajemen, Dan Kemampuan Teknik Pemakai Sistem Informasi Akuntansi Pada Kinerja Individu. E-Jurnal Akuntansi, 6(1), 33-45.

Antari, K. R. W., Diatmika, I. P. G., \& Adiputra, I. M. P. (2015). Faktor-Faktor yang Berpengaruh Terhadap Kinerja Sistem Informasi Akuntansi pada Bank Perkreditan Rakyat di Kabupaten Buleleng. E-Journal S1 Ak Universitas Pendidikan Ganesha.

Ardiwinata, I. G. N. P., \& Sujana, I. K. (2019). Pengaruh Kemampuan Teknik Personal, Keterlibatan Pemakai, Pelatihan Dan Pendidikan Pada Kinerja Sistem Informasi Akuntansi. E-Jurnal Akuntansi. https:// doi.org/10.24843/ eja.2019.v27.i03.p09

Ariyanto, D., Dewi, A. A., \& Jhuniantara, I. M. G. (2020). Perceived learning assistance and perceived community building assistance: Study on e-learning system. Systematic Reviews in Pharmacy, 11(12), 330-339. https://doi.org/10.31838/srp.2020.12.53

Ariyanto, D., Subroto, B., Purnomosidhi, B., \& Rosidi. (2014). Does the Balinese Tri Hita Karana Culture Affect the Adoption and Usage of Information Technology Systems? Information and Knowledge Management.

Damana, A. W. A., \& Suardikha, I. M. S. (2016). Pengaruh Keterlibatan Pemakai, Pelatihan, Ukuran Organisasi Dan Keahlian Pemakai Terhadap Kinerja Sistem Informasi Akuntansi. E-Jurnal Akuntansi, 14(2), 1452-1480.

Davis, F D. (1985). A technology acceptance model for empirically testing new enduser information systems: Theory and results. Management, Ph.D.(May), 291. https://doi.org/oclc/56932490

Davis, Fred D. (1989). Perceived usefulness, perceived ease of use, and user acceptance of information technology. MIS Quarterly: Management Information Systems, 13(3), 319-339. https:// doi.org/10.2307/249008

Davis, Fred D., \& Venkatesh, V. (1996). A critical assessment of potential measurement biases in the technology acceptance model: Three experiments. 
International Journal of Human Computer
https://doi.org/10.1006/ijhc.1996.0040 Studies.

Fatmawati, I., Cahyono, D., \& Maharani, A. (2019). Pengaruh Partisipasi Pemakai Sistem Informasi, Kemampuan Pemakai Sistem Informasi, Ukuran Organisasi Terhadap Kinerja Sistem Informasi Akuntansi. International Journal of Social Science and Business, 3(1), 11. https://doi.org/10.23887/ijssb.v3i1.17159

Gefen, D., \& Straub, D. (2000). The Relative Importance of Perceived Ease of Use in IS Adoption: A Study of E-Commerce Adoption. Journal of the Association for Information Systems. https:// doi.org/10.17705/1jais.00008

Goodhue, D. L., \& Thompson, R. L. (1995). Task-technology fit and individual performance. MIS Quarterly: Management Information Systems. https://doi.org/10.2307/249689

Insani, A. (2017). Faktor-faktor yang mempengaruhi Kinerja Sistem Informasi Akuntansi (Studi Pada PT Angkasa Pura I Bandara Adi Sumarno). Jurnal Bisnis Dan Akuntansi.

Jayantara, I. ketut, \& Dharmadiaksa, I. B. (2016). Pengaruh Kemampuan Teknik Pemakai Dan Efektivitas Sistem Informasi Akuntansi (Sia)Terhadap Kinerja Individual. E-Jurnal Universitas Udayana, 17, 2145-2170.

Jayanti, I. K. M., Yuniarta, G. A., \& Julianto, P. (2017). Pengaruh Kemampuan Teknik Personal, Pendidikan dan Pelatihan Pengguna Serta Dukungan Manajemen Puncak Terhadap Kinerja Sistem Informasi Akuntansi Pada SPPBE di Kabupaten Tabanan. E-Journal S1 Ak Universitas Pendidikan Ganesha, $8(2)$, $1-12$. https:/ / www.google.com/url?sa $=t \& r c t=j \& q=\& e s r c=s \&$ source $=w e b \& c d=\& c$ $\mathrm{ad}=$ rja\&uact $=8 \&$ ved=2ahUKEwih7YjEjO3qAhUNfisKHfgpC24QFjAIegQIC BAB\&url=https\%3A\%2F\%2Fejournal.undiksha.ac.id\%2Findex.php\%2FS1ak \%2Farticle\%2Fdownload\%2F13271\%2F8350\&usg=AOvVaw3ca3GrrSOId5T qDoLyQW

Juliarsa, G. (2012). Analisis Faktor-Faktor Yang Mempengaruhi Kinerja Sistem Informasi Akuntansi Pada LPD Di Kecamatan Denpasar Utara. E-Jurnal Akuntansi.

Kharisma, I. A. M., \& Juliarsa, G. (2017). Pengaruh Keterlibatan Pemakai, Kemampuan Pemakai, Pelatihan dan Pendidikan Pemakai Terhadap Kinerja Sistem Informasi Akuntansi. E-Jurnnal Akuntansi Universitas Udayana, 19(3), 2527-2555.

Kurniawati, N. P. A. Y., \& Dwirandra, A. A. N. B. (2017). Pengaruh Partisipasi Pemakai Dan Ketidakpastian Tugas Pada Kinerja Sia Dengan Ukuran Organisasi Sebagai Variabel Moderasi. E-Jurnal Akuntansi Universitas Udayana, 19(2),

1174-1201. https://ojs.unud.ac.id/index.php/Akuntansi/article/view/27401/18701

Mardiana, I. G. E. P., Sinarwati, N. K., \& Atmadja, A. T. (2014). Analisis FaktorFaktor yang Mempengaruhi Kinerja Perkreditan Desa (LPD) di Kecamatan Susut. E-Journal S1 Ak Universitas Pendidikan Ganesha, 2(1). https:// ejournal.undiksha.ac.id/index.php/S1ak/article/view/4374/3378

Marfuah, M., \& Handoko, A. (2012). Determinan Kinerja Sistem Informasi Akuntansi: Studi Empiris Pada Bank Syariah Di Wilayah Daerah Istimewa 
Yogyakarta. Jurnal Ekonomi Dan Keuangan Islam, 2(1), 52-63.

Muliartha RM, K. (2020). Human Development Index, Liquidity Risk, Credit Risk and Financial Performance of Rural Credit Institutions in Bali. Jurnal Ilmiah Akuntansi Dan Bisnis, 252-267. https://doi.org/10.24843/jiab.2020.v15.i02.p08

Nayaka, A. . B. S., \& Suardikha, I. M. S. (2019). Kepuasan Kerja dan Integritas sebagai Pemoderasi Pengaruh Penerapan Sistem Informasi Akuntansi pada Kinerja Karyawan. E-Jurnal Akuntansi, 26, 454. https://doi.org/10.24843/eja.2019.v26.i01.p17

O’Brien, J. A., \& Marakas, G. M. (2010). Management System Information. In McGraw-Hill Irwin.

Pradnyana, I. G. M. A., \& Dharmadiaksa, I. B. (2018). Pengaruh Kemampuan Personal, Pelatihan Kerja, dan Keterlibatan Pemakai terhadap Kinerja Sistem Informasi Akuntansi. E-Jurnal Akuntansi. https://doi.org/10.24843/eja.2018.v25.i02.p23

Satria, P. A., \& Dewi, P. P. (2019). Faktor-Faktor Yang Mempengaruhi Kinerja Sistem Informasi Akuntansi: Studi Kasus Pada Koperasi Simpan Pinjam Di Kabupaten Gianyar. Jurnal Ilmiah Akuntansi Dan Bisnis, 4(1), 81. https://doi.org/10.38043/jiab.v4i1.2148

Suryawarman, A., \& Widhiyani, N. (2012). Faktor-Faktor yang Mempengaruhi Kinerja Sistem Informasi Akuntansi pada Restoran Waralaba Asing di Kota Denpasar. E-Jurnal Akuntansi.

Venkatesh, V., \& Davis, F. D. (2000). A Theoretical Extension of the Technology Acceptance Model: Four Longitudinal Field Studies. Management Science, $46(2)$,

186-204. https://doi.org/http://dx.doi.org/10.1287/mnsc.46.2.186.11926

Veriana, P., \& Budiartha, I. (2016). Pengaruh Efektivitas Penerapan Sistem Informasi Akuntansi, Budaya Organisasi Dan Kesesuaian Tugas Pada Kinerja Karyawan. E-Jurnal Akuntansi.

West, J., \& Bhattacharya, M. (2016). Intelligent financial fraud detection: A comprehensive review. In Computers and Security. https://doi.org/10.1016/j.cose.2015.09.005

Widyantari, N. W. L., \& Suardikha, I. M. S. (2016). Pengaruh Pelatihan Dan Pendidikan, Pengalaman Kerja Dan Partisipasi Manajemen Pada Efektivitas Penggunaan Sistem Informasi Akuntansi. E-Jurnal Akuntansi Universitas Udayana, 17(2), 1546-1574. https://ojs.unud.ac.id/index.php/Akuntansi/article/view/23355

Wirawan, B. S., \& Suardikha, I. M. S. (2016). Faktor-Faktor Yang Mempengaruhi Kinerja Individual Pada Bank Perkreditan Rakyat Di Kabupaten Badung. EJurnal Akuntansi Universitas Udayana, 17(3), 2352-2383. https://ojs.unud.ac.id/index.php/Akuntansi/article/view/24557 